UDC 159.942 .5

DOI: $10.52534 / \mathrm{msu}-$ pp.7(2).2021.118-124

\author{
Liudmyla I. Moroz ${ }^{\star}$, Svitlana Yu. Dikhtiarenko, Olena O. Andrusik \\ Pavlo Tychyna Uman State Pedagogical University \\ 20300, 2 Sadova Str., Uman, Ukraine
}

\title{
Emotional Resilience as a Major Factor in the Mental Health of Prospective University Students
}

\author{
Article's History: \\ Received: 02.02.2021 \\ Revised: 25.04 .2021 \\ Accepted: 30.05.2021
}

\section{Suggested Citation:}

Moroz, L.I., Dikhtiarenko, S.Yu., \& Andrusik, O.O. (2021). Emotional resilience as a major factor in the mental health of prospective university students. Scientific Bulletin of Mukachevo State University. Series "Pedagogy and Psychology", 7(2), 118-124.

\begin{abstract}
This study investigates the issues of emotional stability as the main factor in the mental health of students of modern higher educational institutions. The relevance of the subject matter is conditioned by the high psychological and psycho-emotional stress that students of many specialties of modern higher educational institutions have to face during their studying, as well as the need for high psychological and emotional stability to handle such stress and successfully complete the training. The leading approach in this study is a combination of a system analysis of the influence of emotional overload on students of modern higher educational institutions during their training with the study of the features of increasing emotional stability in conditions of psychological overload during lectures at a university, which have a considerable impact on the psyche of a student and can cause numerous nervous breakdowns. The results of this study clearly emphasise the importance of the emotional stability of prospective university students as a factor that prevents the development of disorders of their mental health, and also necessitates the development of emotional stability in modern prospective university students to create a reliable, highquality basis for strengthening mental health. The results and conclusions of this study are of substantial importance for students of modern higher educational institutions, university teachers, as well as for numerous researchers of the issues of improving emotional and psychological stability in conditions of high loads associated with intense mental activity inherent in both students and representatives of various spheres of mental labour
\end{abstract}

Keywords: mental health, higher education, psychological stress, psychological stability, educational activity

\section{INTRODUCTION}

The problem of emotional resilience of modern students is acute due to the high academic loads, which modern students of higher education institutions have to face during their studies at the university. In this context, this refers to a considerable number of academic hours within educational and professional programmes, the volume of educational tasks, as well as the increasingly complex learning process in general, which is due to the high intensity of science and technology development in modern conditions [1]. In such conditions, the development of an appropriate level of psychological and emotional resilience among higher education students is a prerequisite for maintaining their psychological health and achieving success in high-quality mastery of their future profession [2].
Professional development of future specialists takes place even at the stage of their training in higher education institutions, which is extremely important in this context. Active, purposeful, and conscious self-affirmation of the individual in the future profession begins with listening to lectures, performing practical tasks aimed at obtaining initial skills within the chosen specialisation [3]. Proper organisation of group and independent work of student plays an important role from the point of view of the effectiveness of the entire educational process, contributes to the highest quality acquirement of educational material, as well as obtaining theoretical and practical skills necessary for the development of a higher education institution student in professional terms, as a competent specialist in chosen profession. 
Both the emotional and psychological overload of a student during training can be a serious threat to his mental health, especially if he has a highly developed vulnerability and is prone to a painful response to numerous irritating factors of the educational process [4]. The development of emotional resilience is extremely important in this case, as it allows the student to remain calm even in the most difficult situations that arise in the learning process, and successfully and efficiently acquire the proposed educational material. Emotional resilience, as the main factor in maintaining a student's mental health, is also important from the point of view of ensuring an appropriate level of performance, developing the ability to perform more tasks within the training programme. In general, the student's emotional resilience is trained throughout his education $[5 ; 6]$.

Emotionally stable students, in the context of global computerisation of higher education institutions and the external environment, are capable of processing considerable amounts of knowledge in a timely manner within the framework of the proposed training programme and adequately perceive the requirements for future specialists in modern conditions, which is a mandatory factor for achieving high results both in training and in further professional activities.

\section{MATERIALS AND METHODS}

The leading approach in this study is a combination of systematic analysis of the impact of emotional overload on students. A systematic analysis of the impact of emotional and psychological stress experienced by modern students during their studies, combined with an analytical study of the features of increasing their emotional resilience, ensures a clear picture of scientific research.

The theoretical basis of this research work is numerous studies of Ukrainian and, mainly, foreign scientists, devoted to the role of the emotional factor in students training in modern conditions, from the point of view of preserving their mental health and the development of students' complete and integral set of competences necessary for high-quality acquirement of the programme of an education institution and the development of psychological qualities that predict success in terms of development as a future specialist in a given professional activity. In order to facilitate the perception of the information provided and create the most objective, high-quality picture of scientific research, all materials taken in the order of citation from national sources and given in this scientific study were translated into English.

This scientific study was conducted in three stages:

1. At the first stage of this scientific research, a theoretical analysis of available research in the field of assessing the category of students' emotional resilience as the main factor of their mental health was performed. This theoretical study was aimed at identifying the level of completeness of the current system of views in scientific circles on the issues included in the topic of this research work, as well as the main methodological approaches proposed for their practical solution.

2. At the second stage of this scientific study, a systematic analysis of the impact of emotional overload on students during their studies was performed. In addition, at this stage of the scientific work, an analytical comparison of the results obtained in the course of the study was made with other researchers' results and conclusions of the problem stated in the framework of this paper.

3. At the final stage of this research work, the conclusions were formulated based on the results of the entire complex of scientific research within the framework of the set of issues stated in the research topic. In general, the results and conclusions of this scientific research are an objective and complete reflection of the entire complex of studies conducted in order to form an objective picture of emotional resilience as the main factor of mental health of prospective university students.

\section{RESULTS AND DISCUSSION}

Emotional resilience is one of the most important qualities of a graduate of any high education institution, which determines his ability to adapt within the chosen profession and prospects for further growth. At the same time, a high level of emotional resilience, both for students and young specialists, contributes to the preservation of mental health and prevents the development of professional burnout and personal deformity, in relation to all areas of activity without exception [7]. Notably that in the student environment, the problem of forming emotional and psychological resilience is extremely acute. It is the age of students that is considered to be the most favourable in terms of the prospects for studying, obtaining higher education, and further professional adaptation. At this time the prospective student of a university receives a full set of skills, theoretical and practical abilities, and professional competences that in the future will contribute to the development of his personality within the chosen profession. This means that the age from 17 to 23-25 years should be considered the most favourable from the point of view of the prospects for forming the proper level of emotional and psychological resilience of the individual.

The educational process within the higher education institution includes the following main components: organisational components (lectures, practical classes, seminars); academic research work, which provides for students' independent activity when studying certain disciplines of the educational and professional programme; productive practice, which includes performing purely practical operations that are as close as possible to the realities of further activities within the chosen profession. The development of psychological and emotional resilience of higher education students occurs gradually, as they master the programme of the education institution. Numerous researchers have noticed that in most cases, high indicators of emotional resilience are achieved by students before the third or fourth year of study, and only in some cases this happens earlier. At the same time, the acquisition of the necessary life experience for professional and personal development occurs only through the assimilation of new knowledge, both theoretical and practical. Only practical classes with the application of the obtained theoretical knowledge in 
the real field contribute both to the qualitative development of competences necessary for conducting professional activities in the future, as well as to strengthening the emotional resilience of higher education students at all stages of their study.

The diagram below demonstrates the main components of the student's emotional resilience, which are formed in the process of mastering the educational and professional programme (Fig. 1). It should be noted that the presented data are of generalised character and may change depending on the target orientation of training in a particular education institution.

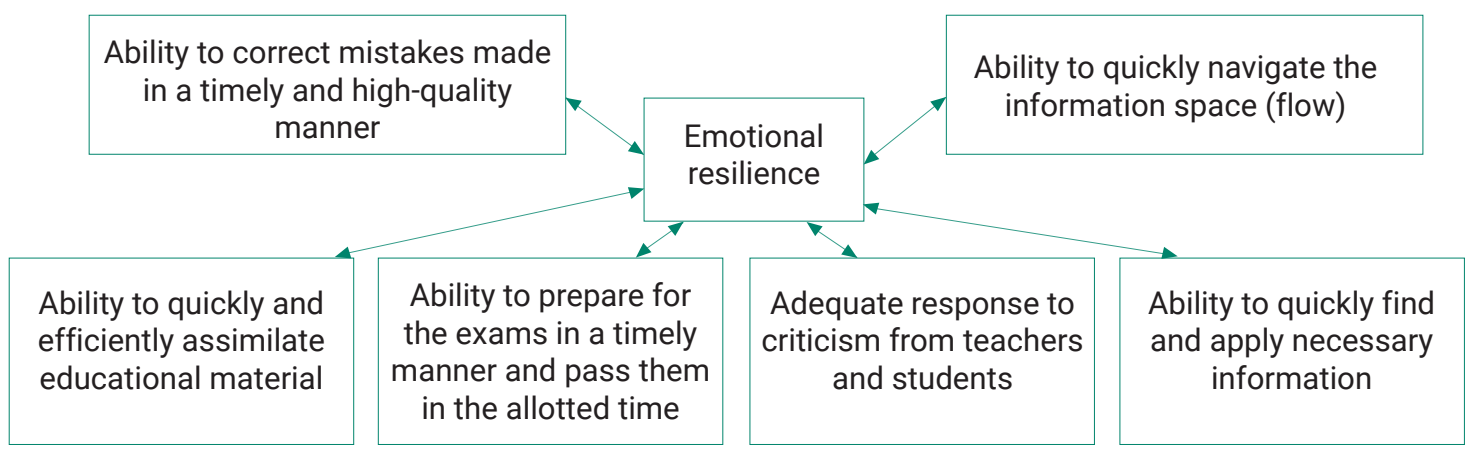

Figure 1. The main components of the student's emotional resilience that are formed in the educational process

As follows from the information provided in Figure 1, an ability to adequately perceive criticism from teachers and other students is a mandatory component of the proper level of modern student's emotional resilience. In addition, one of the important factors in this context is the ability to quickly find the necessary information and apply it in practice in order to obtain high-quality results in a particular field of knowledge. As practice shows, not all students and even graduates of higher education institutions have such competences, which subsequently has a very negative impact on their professional activities.

The most important component of a well-formed psychological resilience of a modern student is the ability to correct mistakes made in a timely and high-quality manner, as well as their adequate perception. A student with a high level of emotional resilience is able to calmly respond to the fact of making any mistakes, regardless of who points them out to him, as well as correct them in a timely and high-quality manner, trying to prevent them in the future.

The above ability to quickly search for the necessary information implies the ability to quickly navigate the information field, which is important in the conditions of modern comprehensive entry of the Internet into everyday life and the educational process. This competence involves achieving a certain level of literacy in a particular type of information, which allows quickly finding the necessary elements in the information space and successfully apply them to solve certain tasks. This is associated with the ability to quickly and efficiently process educational material, as well as the ability to properly build one's own preparation for passing control modules and exams at a specially designated calendar time and without accumulating debts.

From the point of view of the role of emotional resilience in preserving the mental health of modern students, it is of great importance to form their ability to adequately respond to possible failures in the learning process associated with difficulties in mastering individual blocks of the curriculum or its disciplines as a whole. Various situations that arise at the stages of educational activity can have a destructive effect on the psyche, especially if they arise due to the deterioration of the student's relationship with others, whether with teachers or students [8]. High-quality interaction between the student and the teacher plays a huge role, both in achieving the final success of the educational process, and in terms of creating a microclimate that contributes to achieving high learning results. The proficiency in student's communication skills largely determines the level of his knowledge and the speed of development of professional competences necessary for further activities.

Not less important is the student's ability to find and maintain motivation to attend lectures and practical classes in a timely manner, as well as to develop their own motivational and sense bearing sphere, focus on success and self-development, and achieve high academic results. Various motivating situations in the learning process, such as the opportunity to get an increased scholarship with better academic performance, go on vacation earlier when passing exams earlier than the set calendar time, etc., should serve as a factor that stimulates the student's personal and professional development, which is directly related to achieving a high level of emotional resilience [9]. This determines the function of emotional resilience as the main factor in achieving a high level of mental health of a higher education student since only a person with high emotional and psychological resilience will be able to process large amounts of information in modern conditions in the process of studying in the higher education institution in a timely and high-quality manner, without significant harm to mental health.

Taking into account the high rate of modernisation of the current higher education system, the competencybased approach to training a student should be focused on ensuring the success of a graduate of the higher education institution in the modern labour market, with its changing priorities. In modern conditions, a graduate of a higher education institution should have the skills to analyse their own professional activities and the ability to monitor their psychological state when performing narrow professional tasks directly related to their work [10]. The emotional resilience of a young specialist plays a crucial role in this 
context. Training in higher education institutions is usually considered the most important stage of professional development, in other words, active, conscious affirmation of the individual in a professional position based on the assimilation of the established system of knowledge, norms, values, and mastering professional skills. Notably, students have different attitudes to learning, but at the same time, a higher education student who strives to achieve success in the chosen profession is characterised by activity, the ability to independently organise his own activities within the framework of acquiring certain competences. It is characterised by a specific orientation of cognitive and communicative activity to solving particular professionally-oriented tasks. The correct organisation of the student's activity system should be considered one of the main factors of emotional resilience of his personality, and its absence can be a serious obstacle to this [11].

In the conditions of modern society, the development of each individual person's potential is of great importance, and the higher education system plays a very important role in this context. Achieving success in the future professional activity by a modern student is impossible without a clearly built relationship between the emotional, personal, and motivational spheres, the quality of modern students' life in the information space of a higher education institution [12] This determines the need for a deep study of the emotional component of modern students' life and the importance of conducting research in this area. A separate role in the development of modern students' emotional resilience is played by interpersonal relationships that arise between students in the learning process. The development of the ability to effectively build relationships with both teachers and other students is one of the characteristic components of a sufficient level of student's emotional resilience, his sociability, and the ability to find himself in society. It is also important to be able to listen to and hear others, calmly accept criticism, and be able to negotiate even in the most difficult life situations.

Emotional resilience is one of the least developed and formed qualities of a modern personality, regardless of its type of activity and age. As one of the forms of adaptive abilities of a person, emotional resilience implies the ability to track any emotional experiences, control over them, and the ability not to give in to emotions in any, even the most difficult situations. Emotional resilience should be considered an integral property of the mental organisation of the individual, which is manifested in the ability to overcome states of excessive emotional excitation characteristic of performing complex activities [13]. This category can be defined as a stable susceptibility of the individual to destructive emotional states and influences of various conditions, both external and internal. Due to high emotional resilience, the negative effects of strong emotional experiences are maximally reduced for a particular person, the destructive impact of stressful factors on the body weakens, and readiness for action in the most difficult and problematic situations increases. Emotional resilience can be considered as a result of functioning of an integral system of emotional self-regulation of human body, which integrally characterises its abilities for any kind of activity. Modern students who are getting higher education in the era of high information technologies and Internet entry in almost all spheres of life can rightfully be classified as a group with a high risk of developing diseases of the nervous system in general and mental disorders in particular. This is due to the increasing mental, cognitive, and emotional stress, the need to adapt to new learning conditions, as well as to form new, professionally determined interpersonal relationships. The motivation for obtaining higher education in modern conditions is determined not only by the need for professional orientation, but also by the needs for obtaining high-quality knowledge, which form the personality structure of the future specialist [14]. The emotional status of a modern higher education student determines the further area of his activities both when studying at a higher education institution and in the future, when performing his professional duties. The high level of mental self-organisation of a higher education student is crucial from the point of view of his ability to adapt in a timely manner to the realities of the educational environment and adequately perceive the main contradiction of the modern higher education system, which is expressed in the discrepancy between the rapid rate of complication of information entering the modern educational field and the possibilities of its assimilation by modern students, whose capabilities are a priori limited [15].

In this context, of particular importance is the ability of modern students to resist emotional burnout, which manifests itself in the psychological coping mechanism, characterised by partial or complete disconnection of emotions as a response to psychological impact that can traumatise. Emotional burnout most often occurs at a young age, in conditions of lack of life and practical experience in specific areas. The psychological researches conducted in recent years allows defining emotional burnout as an acquired stereotype of emotional behaviour, during which there is a gradual loss of physical, cognitive, and emotional energy by an individual, which manifests itself in the occurrence of characteristic symptoms of mental and emotional exhaustion, physical fatigue, and indifference to the results achieved [16]. In the conditions of the modern higher education system, it is essential to pursue the concept of humane attitude towards students, which is manifested in the recognition of their self-worth, respect for the needs of personality-oriented learning, which is based the student's personality, and the main task is the development of this personality. The selection of a complex of individual educational influences determines the qualitative differentiation of the entire learning process, taking into account the subjective experience of each higher education student separately.

In some cases, the development of a high level of emotional resilience of modern higher education students implies the need to conduct individual classes within the framework of training in higher education institutions, which involve placing emphasis on personal experience, which will need to be developed and multiplied in the future. In such situations, students are required to have a high level of self-control, self-organisation, the ability to 
adequately assess their actions, and the ability to work on mistakes in order to prevent their repetition in the future. All these factors will contribute to the emergence of new emotions that encourage students to take action and motivate to achieve high academic results, which is one of the important manifestations of their emotional resilience [18].

The socio-psychological sphere of a modern student's personality is subject to constant structural changes, which can both positively influence his professional and social development, and significantly complicate his further self-realisation in society. It is the issue of emotional resilience of a higher education student that plays a primary role in this context. Students with a high level of emotional resilience perceive life and educational difficulties more easily, are less susceptible to depression and sudden mood swings, which generally has a positive effect on their ability to withstand the difficulties that inevitably arise in the development of various professional and personal competences. At the same time, people with a low level of self-esteem and emotional resilience are less capable of introspection, search, and recognition of strengths and weaknesses of their personality, which in a complex negatively affects the prospects for their personal development and self-realisation [19].

In the context of mastering an educational and professional programme for the development of a student's emotional resilience as a factor that significantly affects the overall level of his further mental health, it is extremely important to conduct timely psychological correction of certain aspects of behaviour on the part of an experienced teacher. Unfortunately, nowadays, the service for providing psychological assistance to students of higher education institutions has not yet received proper development and promotion, so that it is possible to discuss the qualitative introduction of the principles of psychological control of the students' state in the learning process [20]. However, the first steps in this direction have already been taken, and a number of modern humanitarian universities have already developed and implemented technologies for providing psychological assistance to students in crisis life situations. Such measures in prospect can significantly affect the entire higher education system, contributing to the qualitative development of a high level of emotional resilience among modern students, which will contribute to the preservation of their mental health in general.

A modern successful person who is characterised by a high level of adaptation, both to social conditions and to the realities of student and professional life, has the ability to conduct introspection, if necessary, with the identification of the main factors that both determine his success in society and professional environment, and prevent the achievement of high results in a particular type of activity. In this aspect, the factor of the presence or absence of communicative experience is of great importance, which contributes, in conditions of a high level of individual's emotional resilience, to adequately assess the judgments of others about themselves, without running into extremes and depressive states in cases where the opinion of others is not quite as expected. In such situations, the ability to defend one's own point of view on the surrounding events and phenomena is of great importance, as well as to accept objective criticism, if such criticism contributes to the improvement of the individual as a whole [21]. In this case, it will be possible to mention mental adequacy of the individual, his tendency to introspection and the ability to draw correct conclusions from situations, which generally allows discussing the presence of a high level of development of emotional and psychological resilience.

Modern students develop simultaneously in various fields directly or indirectly related to their main task, which is to get higher education and master their chosen profession. The emotional sphere of their development is extremely important both from the point of view of further professional growth, and from the point of view of assessing the prospects for personal growth. The development of psychological and emotional resilience of modern higher education students should not be neglected since in the future this may turn into significant problems, both psychological and professional.

\section{CONCLUSIONS}

A scientific study of various aspects of assessing emotional resilience as the main factor in the mental health of higher education students has led to the following conclusions. The development of emotional resilience of modern students of higher education institutions is a very important factor in terms of forming their ability to learn, to fully assimilate the material of the curriculum, and form the competencies necessary for the successful implementation of further professional activities. Emotional resilience is formed in students gradually, throughout the entire period of mastering the university programme, and is one of the essential factors of the integrity of their mental health and the quality of professional training. Only an emotionally stable person who endures the stresses and experiences associated with various unfavourable aspects of his professional activity can be considered a high-class specialist who can efficiently solve any professional tasks. In this context, the need to develop emotional resilience among higher education students during the entire period of study of their chosen specialisation in the system of modern higher education is explained.

Taking into account the importance of all these circumstances from the point of view of the influence of emotional resilience on the further professional activity of modern higher education institution graduates, it can be concluded that it is necessary to gradually develop this competence in a purely practical way. The emotional resilience can be developed only in direct contact with factors that are crucial in terms of training in the higher education institution, such as lectures and seminars, self-training in free time, passing exams, as well as practical classes aimed directly at mastering skills that are important for future professional activity. At this stage, the student is responsible for the high-quality assimilation of educational material, which is confirmed by the results obtained in intermediate assessments, as well as the development of practical experience when performing tasks that are close to the conditions of professional activity. All this together forms a high level of emotional resilience of the future specialist, which in future will serve as a reliable basis for his mental health and high-quality performance of his professional duties. 


\section{REFERENCES}

[1] Nizette, D., McAllister, M., \& Marks, P. (2020). Stories in mental health (2nd ed.). Oxford: Elsevier.

[2] Safin, O.D., Kravchenko, O.O., \& Mishchenko, M.S. (2020). Ensuring the mental health of inclusive resource center professionals. Uman: Publisher "Sochinsky M.M.".

[3] Tettegah, S., \& Garcia, Y. (2016). Emotions, technology, and health (1st ed). London: Academic Press.

[4] Morrison-Valfre, M. (2016). Foundations of mental health care (6th ed.). Maryland Heights: Mosby.

[5] Hodes, M., \& Gau, S. (2016). Positive mental health, fighting stigma and promoting resiliency for children and adolescents (1st ed.). London: Academic Press.

[6] Bowins, B. (2021). States and processes for mental health (1st ed.). London: Academic Press.

[7] Chen, A. (2019). Stress resilience (1st ed.). London: Academic Press.

[8] Rosmarin, D., \& Koenig, H. (2020). Handbook of spirituality, religion, and mental health (2nd ed.). London: Academic Press.

[9] Koenig, H. (2018). Religion and mental health (1st ed.). London: Academic Press.

[10] Kalinina, T.V., \& Kolyasnikova, M.B. (2016). Formation of emotional stability of students in the conditions of university education. Modern Research of Social Problems, 3-2(59), 109-115.

[11] Sultanova, I.V. (2014). On the problems of the formation of emotional stability in first-year students in the process of educational activity. International Scientific Review, 8, 282-287.

[12] Rozanov, V. (2017). Stress and epigenetics in suicide (1st ed.). London: Academic Press.

[13] Jack-Waugh, A., Ritchie, L., \& MacRae, R. (2018). Assessing the educational impact of the dementia champions programme in Scotland: Implications for evaluating professional dementia education. Nurse Education Today, 71, 205-210.

[14] Diep, N.A., Cocquyt, C., Zhu, C., Vanwing, T., \& Greef, M. (2017). Effects of core self-evaluation and online interaction quality on adults' learning performance and bonding and bridging social capital. The Internet and Higher Education, 34, 41-55.

[15] Ormel, J., Cuijpers, P., Jorm, A., \& Schoevers, R.A. (2020). What is needed to eradicate the depression epidemic, and why. Mental Health \& Prevention, 17, article number 200177.

[16] Hartrey, L., Denieffe, S., \& Wells, J.S.G. (2017). A systematic review of barriers and supports to the participation of students with mental health difficulties in higher education. Mental Health \& Prevention, 6, 26-43.

[17] Thompson, A., \& Broome, M. (2020). Risk factors for psychosis (1st ed.). London: Academic Press.

[18] Schwartz, C., Drexl, K., Fischer, A., Fumi, M., Lowe, B., Naab, S., \& Voderholzer, U. (2019). Universal prevention in eating disorders: A systematic narrative review of recent studies. Mental Health \& Prevention, 14, article number 200162.

[19] Mayor-Silva, L.I., Romero-Saldana, M., Moreno-Pimentel, A.G., Alvarez-Melcon, A., Molina-Luque, R., \& Meneses-Monroy, A. (2021). The role of psychological variables in improving resilience: Comparison of an online intervention with a face-to-face intervention. A randomised controlled clinical trial in students of health sciences. Nurse Education Today, 99, article number 104778.

[20] Vasileiou, K., Barnett, J., Baretto, M., Vines, J., Atkinson, M., Long, K., Bakewell, L., Lawson, S., \& Wilson, M. (2019). Coping with loneliness at University: A qualitative interview study with students in the UK. Mental Health \& Prevention, 13, 21-30.

[21] Zhang, H., Wang, W., Goh, S.H.L., Wu, X.V., \& Morelius, E. (2020). The impact of a three-phase video-assisted debriefing on nursing students' debriefing experiences, perceived stress and facilitators' practices: A mixed methods study. Nurse Education Today, 90, article number 104460. 


\section{Людмила Іванівна Мороз, Світлана Юріївна Діхтяренко, Олена Олександрівна Андрусик}

Уманський державний педагогічний університет імені Павла Тичини 20300, вул. Садова, 2, м. Умань, Україна

\section{Емоційна стійкість як основний фактор психічного здоров'я здобувачів вищої освіти}

Анотація. У даній науково-дослідній роботі розглядаються питання емоційної стійкості як основного фактору психічного здоров'я студентів сучасних закладів вищої освіти. Актуальність заявленої тематики наукового дослідження обумовлюється високими обсягами психологічних і психоемоційних навантажень, з якими змушені стикатися студенти багатьох спеціальностей сучасних ЗВО в період здобуття вищої освіти і необхідністю наявності у них високого рівня психологічної і емоційної стійкості для того, щоб мати можливість впоратися 3 такими навантаженнями і успішно закінчити навчання. Провідним підходом в даній науково-дослідній роботі вибрано поєднання системного аналізу впливу емоційних перевантажень на студентів сучасних вищих навчальних закладів в період їхнього навчання з дослідженням особливостей підвищення емоційної стійкості в умовах психологічних перевантажень при заняттях у 3ВО, що істотно впливають на психіку учня і здатні стати причиною численних нервових зривів. Результати даної науково-дослідної роботи наочно підкреслюють важливість емоційної стійкості здобувачів вищої освіти як фактору, що перешкоджає розвитку порушень їхнього психічного здоров'я, а також свідчать про необхідність розвитку емоційної стійкості сучасних здобувачів вищої освіти, з метою створення надійної, якісної основи для зміцнення емоційної стійкості. Результати та висновки даної науково-дослідної роботи мають істотне значення для студентів сучасних 3ВО, викладачів, а також для численних дослідників питань підвищення рівня емоційної та психологічної стійкості в умовах значних навантажень, пов'язаних з процесами інтенсивної розумової діяльності, властивої як студентам, так і представникам різних сфер розумової праці

Ключові слова: психічне здоров'я, вища освіта, психологічні навантаження, емоційна стійкість, навчальна діяльність 